\author{
Iwona Pomianek \\ Warsaw University of Life Sciences - SGGW
}

\title{
CLASSIFICATION OF BORDER SUBREGIONS OF EASTERN POLAND ACCORDING TO THEIR LEVEL OF SOCIO-ECONOMIC DEVELOPMENT
}

The paper presents the classification of subregions (NUTS 3) with permanent border crossings, in terms of the level of socio-economic development in 2008-2018. The study covered 9 subregions located in the following provinces: Warminsko-Mazurskie, Podlaskie, Lubelskie and Podkarpackie. Application of Hellwig's measure of development made it possible to group subregions according to three categories of the level of development: high, medium and low. The relatively high level of development characterized two metropolitan subregions: Olsztynski and Białostocki. Łomżynski subregion proved to be the weakest, but it was not completely devoid of any development potential. In comparison with the average values in the designated higher development classes, Lomżyński subregion was characterized by: positive natural increase, low values of indices describing ageing of local society and proportion of investment expenditure of local self-government units at a level similar to the leaders of the ranking. However, there is a concern that the relatively low level of spending of the EU funds and the persistent trend of population migration outflow, due to global trends of population ageing and depopulation of rural areas, may negatively affect the socio-economic situation of the subregion in the future.

Key words: socio-economic development, demographic factors, infrastructure, spatial peripherality, economic peripherality, NUTS 3, Hellwig's measure of development JEL Code: R11

\section{Introduction}

Poland's eastern border areas, which are also the external border of the European Union, are often perceived as peripheral ${ }^{1}$ not only in geographical but also in developmental terms. Peripherality, by definition, is the result of many long-lasting processes that increase variation between regions, resulting in the separation of central and peripheral areas in the territory ${ }^{2}$. Taking into account the spatial criterion - areas with unfavourable

\footnotetext{
${ }^{1}$ I. Pomianek: Poziom rozwoju społeczno-gospodarczego obszarów wiejskich województwa warmińskomazurskiego. Acta Sci. Pol. Oeconomia, 9(3)/2010, 227-239; J. Rakowska, Zróżnicowanie poziomu rozwoju gmin Polski Wschodniej. Roczniki Naukowe Stowarzyszenia Ekonomistów Rolnictwa i Agrobiznesu, T. 13, z. 2, 2011, 392-397; Balińska A.: Znaczenie turystyki w rozwoju gmin wiejskich na przykładzie obszarów peryferyjnych wschodniego pogranicza Polski. Wydawnictwo SGGW, Warszawa 2016.

${ }^{2}$ K. Leszczewska: Aktywność ekonomiczna regionów peryferyjnych. Nierówności Społeczne a Wzrost Gospodarczy, zeszyt 17, 2010, 215-225; D. Panzera, P. Postiglione: Economic growth in Italian NUTS 3 provinces. The Annals of Regional Science 53(1), 2014, 273-293; A. Jakubowski, U. Bronisz: Granica Unii Europejskiej jako czynnik (dez)aktywizujący rozwój i konkurencyjność obszarów przygranicznych [w:] A. Grynia (red.): Wybrane aspekty rozwoju i konkurencyjności nowych krajów członkowskich Unii Europejskiej, Wydział Ekonomiczno-Informatyczny w Wilnie, Uniwersytet w Białymstoku, Wilno 2015, 638; J. Benedek, N.C. Veress: Economic disparities and changes in the convergence of the Romanian NUTS 2 and NUTS 3 regions. Romanian Review of Regional Studies, Volume IX, Number 1, 2013, 85-90; T. G. Grosse: Wybrane koncepcje teoretyczne i doświadczenia praktyczne dotyczące rozwoju regionów peryferyjnych. Studia
} 
transportation connections with remote economic centres are defined as peripheral (e.g. in the theory of core and periphery) $)^{3}$. Assuming the economic criterion, peripheral areas include regions with low population density, low-urbanized, mainly rural, with a low level of economic development (GDP per capita below $75 \%$ of the EU mean) ${ }^{4}$. Peripherality also results from long-lasting processes that deepen interregional diversity, leading to the separation of central regions and peripheries in the territory. Therefore, peripheral regions have low economic potential compared to other areas of the country, and consequently - lower investment attractiveness resulting, among others, from insufficient markets, low transport accessibility, poor economic infrastructure (business environment) or lower, in comparison with other areas, quality of labour resources.

A. Czarnecki emphasizes the importance of location factors in economic activity related to location rent in determining initiation and development of non-agricultural functions in rural areas. The degree of spatial diversification (especially in rural areas) in terms of the level of economic activity, diversity of the structure or the level of saturation with enterprises, depends not only on the entrepreneurship and initiatives of residents, social capital, the economic situation of a municipality or a region. Spatial location factors play a special role, including location in the zone of direct influence of larger cities, proximity to important transportation routes, density of the urban network, location in the centre or on the peripheries of the region, or the administrative status of the municipality ${ }^{6}$.

In addition to location conditions, the financial capabilities of municipalities and poviats are also a factor in the economic development of subregions ${ }^{7}$ : revenues to the local budget, financial independence (autonomy), investment activity as well as acquisition and use of external financing sources ${ }^{8}$. On the other hand, investment projects, mostly in the area of technical infrastructure, should be conducted in such a

Regionalne i Lokalne, Nr 1(27)2007, 34; I. Lengyel, B. Kotosz: The Catching up Processes of the Regions of the Visegrad Group Countries. Comparative Economic Research, 2018, 21, nr 4, 5-24; M. Proniewski: Rozwój regionów peryferyjnych w Unii Europejskiej, Wydawnictwo Uniwersytetu w Białymstoku, Białystok 2012, 130.

${ }^{3}$ J.T. Hryniewicz, Teoria „centrum-peryferie” w epoce globalizacji. Studia Regionalne i Lokalne, Nr 2(40) 2010, 5-27.

${ }^{4}$ R. Rudnicki: Peryferyjność położenia geograficzno-komunikacyjnego a wybrane wskaźniki rozwoju powiatów ziemskich, [w:] M. Wesołowska (red.): Wiejskie obszary peryferyjne - uwarunkowania i czynniki aktywizacji. Studia Obszarów Wiejskich, tom 26, Warszawa 2011, 36.

${ }^{5}$ K. Leszczewska: Aktywność ekonomiczna regionów peryferyjnych. Nierówności Społeczne a Wzrost Gospodarczy, zeszyt 17, 2010, s. 215-225.

${ }^{6}$ A. Czarnecki: Wpływ czynników lokalizacyjnych na rozwój działalności pozarolniczej na obszarach wiejskich. Roczniki Naukowe SERiA, tom VIII, zeszyt 4, 2006, s. 78.

${ }^{7}$ A. Parlińska, H.B. Yavuz: Finances of municipalities governments in Poland and Turkey. Acta Sci. Pol. Oeconomia 16(4)2017, 123-132; Ł. Satoła, P. Pogan: Trwały rozwój lokalny w gminach o zróżnicowanej sytuacji finansowej, w: Zeszyty Naukowe Szkoły Głównej Gospodarstwa Wiejskiego w Warszawie Ekonomika i Organizacja Gospodarki Żywnościowej, nr 116, 2016, 119-131; M. Podstawka, B. Suchodolski: Rozwój lokalny i jego wyznaczniki na poziomie powiatu. Marketing i Rynek, r. 23, nr 10/2016, CD, 383-393; M. Chrzanowska, N. Drejerska: Statistical Comparative Analysis of Socio-Economic Development Level of Polish Border Regions (NUTS 3), Proceedings of the International Scientific Conference on Quantitative Methods in Economics - Multiple Criteria Decision Making XVIII, Vratna, Slovakia, The Slovak Society for Operations Research, Department of Operations Research and Econometrics, Faculty of Economic Informatics, University of Economics in Bratislava, May 25-27, 2016, 131.

${ }^{8}$ Ł. Satoła: Zróżnicowanie wykorzystania funduszy Unii Europejskiej w układzie centrum - peryferia, Prace Naukowe Uniwersytetu Ekonomicznego we Wrocławiu, nr 320, 2013, 176-185. 
way as to increase attractiveness of the area by removing existing barriers of social and economic development on both local and regional scale 9 . Development of housing and other economic functions is pushing agriculture out of suburban areas towards the periphery. In suburban areas, rapid development of the local non-agricultural labour market and the use of proximity of the urban market can be observed ${ }^{10}$. However, rural areas, located peripherally in relation to urban centres and main transportation routes, show a slight development of non-agricultural labour markets.

According to research conducted by K. Heffner, the number of people living in the countryside does not decrease and changes in rural areas are bidirectional. In the surroundings of urban agglomerations, the number of inhabitants increases (often significantly), while in many peripheral, less reachable, less attractive (e.g. landscape, ecological) zones the rural population is decreasing ${ }^{11}$. The oldest municipalities are located in Eastern Poland, which makes it the oldest region in Poland ${ }^{12}$. As rightly noted by J. Rakowska, in the case of marginalized areas in terms of economic and social development, the aging of local populations, not balanced by the inflow of external human potential, may result in a significant reduction in population, and in extreme cases - lead to depopulation of such areas in a relatively short time, along with all negative social and economic consequences accompanying this process on a local, regional and national scale ${ }^{13}$. This is even more important since - according to research conducted by E. Roszko-Wójtowicz and M. Grzelak - Podkarpackie and WarmińskoMazurskie regions took the last places in the analysis of diversity of the quality of life ${ }^{14}$. According to P. Śleszyński, a significant decrease in population is expected with the aging of the biological structure of the population. These changes will vary in space, and further depopulation of traditional peripheral regions is almost certain ${ }^{15}$.

\section{Aim and methods}

Development is a concept of broad meaning. J.J. Parysek defines development as a process of transition from a given state or form to a more developed, complex, advanced one $^{16}$. The aim of the paper was to compare the level of socio-economic development of Eastern Poland's border subregions, which have border crossings only with the non-EU

\footnotetext{
${ }^{9}$ M. Kowalska (red.), W. Knapik, M. Bogusz, B. Kiełbasa, A. Niedziółka, A. Piotrowska, Ł. Satoła: Rozwój lokalny obszarów wiejskich w perspektywie społeczno-ekonomicznej, Uniwersytet Rolniczy im. Hugona Kołłątaja, Europejskie Centrum Badawcze Drobnych Gospodarstw Rolnych, Kraków 2015, 22.

${ }^{10}$ A. Łapińska: Rola przedsiębiorczości w kreowaniu wielofunkcyjności rozwoju terenów wiejskich. Wieś Jutra, październik 10(123)2008, 8

${ }^{11}$ K. Heffner: Wielofunkcyjność obszarów wiejskich w Polsce rzeczywistość czy mit? [w:] W. Kamińska, K. Heffner (red.): Obszary wiejskie, wielofunkcyjność, migracje, nowe wizje rozwoju, Studia KPZK, 2011, nr 133 , s. 10

12 J. Rakowska, 2016: Zróżnicowanie poziomu starości demograficznej Polski w ujęciu lokalnym, Studia Ekonomiczne i Regionalne = Economic and Regional Studies 2016, T. 9, nr 2, s. 13.

${ }^{13}$ J. Rakowska, 2016: Zróżnicowanie poziomu starości demograficznej Polski w ujęciu lokalnym, Studia Ekonomiczne i Regionalne = Economic and Regional Studies 2016, T. 9, nr 2, s. 22.

${ }^{14}$ E. Roszko-Wójtowicz, M.M. Grzelak: Wielowymiarowe ujęcie zróżnicowania poziomu jakości życia w województwach w Polsce. Zeszyty Naukowe Polityki Europejskie, Finanse i Marketing, nr 69/2018, 211.

15 P. Śleszyński: Demograficzne wyzwania rozwoju regionalnego Polski. [w:] Teoretyczne i aplikacyjne wyzwania współczesnej geografii społeczno-ekonomicznej, Studia KPZK, tom 183/2018, 225-247.

${ }^{16}$ J.J. Parysek: Rozwój społeczno-gospodarczy oraz czynniki i uwarunkowania rozwoju. [w:] Teoretyczne i aplikacyjne wyzwania współczesnej geografii społeczno-ekonomicznej, Studia KPZK, tom 183/2018, 38.
} 
countries (in 2008-2018). Therefore, the analysis was carried out on units of the NUTS-3 level. Table 1 presents the subregions qualified for the analysis. Out of 10 Polish border subregions located along the eastern border of the EU, Suwalski subregion was excluded from further analysis, as it not only does not have a permanent border crossing with Belarus (only periodically active pedestrian, bicycle and river crossing in RudawkaLesnaja), but also borders with the area of Lithuania, where there is no physical barrier between this country and the subregion.

Table 1. Characteristics of the analysed border subregions of Eastern Poland

\begin{tabular}{|c|c|c|c|c|c|c|c|}
\hline \multirow[t]{2}{*}{ No.. } & \multirow[t]{2}{*}{ Subregion } & \multirow[t]{2}{*}{ Region } & \multicolumn{4}{|c|}{$\begin{array}{c}\text { Number of permanent border crossing } \\
\text { points* }\end{array}$} & \multirow{2}{*}{$\begin{array}{l}\text { Qualification } \\
\text { for the study }\end{array}$} \\
\hline & & & road & pedestrian & raile & total & \\
\hline 1 & Elbląski & $\begin{array}{l}\text { Warmińsko- } \\
\text { Mazurskie }\end{array}$ & 2 & 0 & 1 & 3 & + \\
\hline 2 & Olsztyński & $\begin{array}{l}\text { Warmińsko- } \\
\text { Mazurskie }\end{array}$ & 1 & 0 & 2 & 3 & + \\
\hline 3 & Ełcki & $\begin{array}{l}\text { Warmińsko- } \\
\text { Mazurskie }\end{array}$ & 1 & 0 & 0 & 1 & + \\
\hline 4 & Suwalski & Podlaskie & 0 & 0 & 0 & 0 & - \\
\hline 5 & Białostocki & Podlaskie & $2 * *$ & $1 * *$ & 2 & 4 & + \\
\hline 6 & Łomżyński & Podlaskie & 1 & 0 & 2 & 3 & + \\
\hline 7 & Bialski & Lubelskie & 3 & 0 & 1 & 4 & + \\
\hline 8 & $\begin{array}{l}\text { Chełmsko- } \\
\text { Zamojski }\end{array}$ & Lubelskie & 4 & 0 & 3 & 7 & + \\
\hline 9 & Krośnieński & Podkarpackie & 1 & 0 & 1 & 2 & + \\
\hline 10 & Przemyski & Podkarpackie & $3 * *$ & $1 * *$ & 2 & 5 & + \\
\hline
\end{tabular}

* border crossing with Russia, Belarus or Ukraine

** including 1 pedestrian-road crossing

Source: Author's elaboration based on: The map of crossings and objects of the Polish Border Guard (Mapa przejść i obiektów Straży Granicznej) [in:] https://www.strazgraniczna.pl/pl/mapa-przejsc-i-obiektow/ (access: 20.06.2019); https:/granica.gov.pl/przejsciap.php (access: 20.06.2019) and the Local Data Bank of the Statistics Poland (BDL GUS).

To complete the goal formulated in such way, a synthetic measure construction procedure, connecting many variables, was carried out. Data for the construction of the socio-economic development indicator, in addition to the sources listed in Table 1, were taken from the Local Data Bank of the Statistics Poland (the Central Statistical Office, BDL GUS). The construction of the measure consisted of a few stages. In the first stage, an essential selection of features for building the development indicator based on literature studies was made ${ }^{17}$.

\footnotetext{
${ }^{17}$ See, among others: M. Chrzanowska, N. Drejerska: Statistical Comparative Analysis of Socio-Economic Development Level of Polish Border Regions (NUTS 3), Proceedings of the International Scientific Conference on Quantitative Methods in Economics - Multiple Criteria Decision Making XVIII, Vratna, Slovakia, The Slovak Society for Operations Research, Department of Operations Research and Econometrics, Faculty of Economic Informatics, University of Economics in Bratislava, May 25-27, 2016; N. Drejerska, M. Chrzanowska, Pomianek I.: Strefa podmiejska Warszawy: wybrane zagadnienia. Wydawnictwo SGGW, Warszawa 2014; A. Czarnecki: Wpływ czynników lokalizacyjnych na rozwój działalności pozarolniczej na obszarach wiejskich. Roczniki Naukowe SERiA, tom VIII, zeszyt 4, 2006, 78-82; T. Czyż: Poziom rozwoju społeczno-gospodarczego Polski w ujęciu subregionalnym, Przegląd Geograficzny, nr 84/2, 2012, 219-236; K. Leszczewska: Aktywność ekonomiczna regionów peryferyjnych. Nierówności Społeczne a Wzrost Gospodarczy, zeszyt 17, 2010, s. 215-225; A. Łapińska: Rola przedsiębiorczości w kreowaniu wielofunkcyjności rozwoju terenów wiejskich. Wieś Jutra, październik 10(123)2008, 8; J.J. Parysek: Rozwój
} 
Table 2. Diagnostic variables

\begin{tabular}{|c|c|c|c|}
\hline Symbol & Variable & Years & Type \\
\hline $\mathrm{X} 1$ & Fertility rate* & $2008-2018$ & stimulant \\
\hline $\mathrm{X2}$ & Gross reproduction rate* & 20082018 & stimelant \\
\hline $\mathrm{X} 3$ & Population density (population per $1 \mathrm{~km}^{2}$ ) & $2008-2018$ & stimulant \\
\hline $\mathrm{X} 4$ & $\begin{array}{l}\text { Change in the number of residents per } 1,000 \text { population (combining } \\
\text { natural increase and migrations) }\end{array}$ & $2008-2018$ & stimulant \\
\hline$\times 5$ & $\begin{array}{l}\text { Dependency ratio (number of post working age people per } 100 \\
\text { working age people)* }\end{array}$ & 20082018 & destimulant \\
\hline $\mathrm{X} 6$ & Old-age dependency ratio & $2008-2018$ & destimulant \\
\hline $\mathrm{X7}$ & Proportion of population aged $65+*$ & $2010-2018$ & destimulant \\
\hline $\mathrm{X} 8$ & Gross Domestic Product per capita (PLN) & $2008-2016$ & stimulant \\
\hline X9 & Total registered unemployment rate & $2008-2018$ & destimulant \\
\hline $\mathrm{X} 10$ & $\begin{array}{l}\text { Proportion of long-term unemployed (over } 12 \text { months) in population of } \\
\text { unemployed }\end{array}$ & $2008-2018$ & destimulant \\
\hline $\mathrm{X} 11$ & Proportion of unemployed school-leavers in population of unemployed & $2012-2018$ & destimulant \\
\hline $\mathrm{X} 12$ & Proportion of employed in agriculture & $2010-2017$ & destimulant \\
\hline $\mathrm{X} 13$ & Proportion of employed in services & $2010-2017$ & stimulant \\
\hline $\mathrm{X} 14$ & Economic entities registered in the REGON per 10,000 population & $2008-2018$ & stimulant \\
\hline $\mathrm{X} 15$ & $\begin{array}{l}\text { Foundations, associations and secial organizations per } 10,000 \\
\text { population* }\end{array}$ & $2008-2018$ & stimulant \\
\hline $\mathrm{X} 16$ & $\begin{array}{l}\text { The EU funds for municipalities and poviats for financing programmes } \\
\text { and projects (per capita) }\end{array}$ & $2010-2017$ & stimulant \\
\hline $\mathrm{X} 17$ & $\begin{array}{l}\text { Proportion of own revenues of municipalities and poviats in total } \\
\text { budget revenues }(\%)\end{array}$ & $2010-2017$ & stimulant \\
\hline $\mathrm{X} 18$ & $\begin{array}{l}\text { Proportion of investment expenditure of municipalities and poviats in } \\
\text { the total expenditure of municipalities and poviats }\end{array}$ & $2008-2017$ & stimulant \\
\hline $\mathrm{X} 19$ & Number of permanent border crossings (pedestrian, road or rail) & 2018 & stimulant \\
\hline $\mathrm{X} 20$ & $\begin{array}{l}\text { Length of municipal and poviat roads with ground surface in } \mathrm{km} \text { per } \\
100 \mathrm{~km}^{2}\end{array}$ & $2008-2017$ & destimulant \\
\hline $\mathrm{X} 21$ & Length of bike paths per $10,000 \mathrm{~km}^{2}(\mathrm{~km})$ & $2011-2017$ & stimulant \\
\hline $\mathrm{X} 22$ & Number of bed places per 1,000 population & $2008-2018$ & stimulant \\
\hline $\mathrm{X} 23$ & Tourists accommodated per 1,000 population & $2008-2018$ & stimulant \\
\hline
\end{tabular}

* Quasi-constant variables excluded from further analysis.

Source: Author's elaboration based on: The map of crossings and objects of the Polish Border Guard (Mapa przejść i obiektów Straży Granicznej) [in:] https://www.strazgraniczna.pl/pl/mapa-przejsc-i-obiektow/ (access: 20.06.2019); https:/granica.gov.pl/przejsciap.php (access: 20.06.2019) and the Local Data Bank of the Statistics Poland (BDL GUS).

społeczno-gospodarczy oraz czynniki i uwarunkowania rozwoju. [w:] Teoretyczne i aplikacyjne wyzwania współczesnej geografii społeczno-ekonomicznej, Studia KPZK, tom 183/2018, 37-54; M. Podstawka, B. Suchodolski: Rozwój lokalny i jego wyznaczniki na poziomie powiatu. Marketing i Rynek, r. 23, nr 10/2016, CD, 383-393; I. Pomianek: Poziom rozwoju społeczno-gospodarczego obszarów wiejskich województwa warmińsko-mazurskiego. Acta Sci. Pol. Oeconomia, 9(3)/2010, 227-239; J. Rakowska: Zróżnicowanie poziomu rozwoju gmin Polski Wschodniej, Roczniki Naukowe Stowarzyszenia Ekonomistów Rolnictwa i Agrobiznesu, 2011, tom 13, zeszyt 2, 392-397; J. Rakowska: Zróżnicowanie poziomu starości demograficznej Polski w ujęciu lokalnym, Studia Ekonomiczne i Regionalne, tom 9, 2/2016, s. 13-23; E. Roszko-Wójtowicz, M.M. Grzelak: Wielowymiarowe ujęcie zróżnicowania poziomu jakości życia w województwach w Polsce. Zeszyty Naukowe Polityki Europejskie, Finanse i Marketing, 69/2018, 197-214; Ł. Satoła, P. Pogan: Trwały rozwój lokalny w gminach o zróżnicowanej sytuacji finansowej, Zeszyty Naukowe Szkoły Głównej Gospodarstwa Wiejskiego w Warszawie, Ekonomika i Organizacja Gospodarki Żywnościowej, nr 116, 2016, 119-131; M. Stanny: Przestrzenne zróżnicowanie rozwoju obszarów wiejskich w Polsce. Problemy Rozwoju Wsi i Rolnictwa, IRWiR PAN, Warszawa 2013. 
Concerning the formal criteria for selecting variables, measurable, available and complete diagnostic variables were used to construct the measure of subregions' development. Some potential variables, significant in terms of the content, could not be included in the group of analysed variables, because in the LDB some information is not collected at levels below NUTS-2 (voivodships). The years 2008-2018 were adopted as the time range of the analysis. For some variables, this range was not available, so possibly the longest time range was adopted for them (see Table 2).

Preliminary data analysis using a coefficient of variation allowed eliminating quasiconstant variables. The coefficient of variation $V_{j}$ is a relative measure of dispersion, the value of which is determined as the ratio of the standard deviation to the value of the arithmetic mean ${ }^{18}$. The critical value assumed $\mathrm{V} *=0.10$. It allowed eliminating the following variables: X1, X2, X5, X7 and X15. As a result, a set of 18 variables was obtained. Six variables were destimulants, the others were stimulants. Using the taxonomic development measure by Z. Hellwig ${ }^{19}$, the variables enabled division of the examined objects (subregions) into three classes differing in terms of the level of socioeconomic development. It is one of the taxonomic methods, in which the aggregate measure is calculated as a synthetic indicator of the taxonomic distance of an object from the theoretical development pattern (the higher the value of the measure, the closer the object is to the pattern). The development measure $\left(d_{i}\right)$ usually takes values in the range $[0 ; 1]$. The following classes (groups of subregions) have been distinguished:

- $1^{\text {st }}$ class (high level of development): $d_{i}>\bar{d}_{l}+S_{d_{i}}$,

$-2^{\text {nd }}$ class (medium level of development): $\bar{d}_{l}-S_{d_{i}}<d_{i} \leq \bar{d}_{l}+S_{d_{i}}$,

- $3^{\text {rd }}$ class (low level of development): $d_{i} \leq \bar{d}_{l}-S_{d_{i}}$,

where: $d_{i}$ is the value of synthetic measure calculated by Hellwig's method, $\bar{d}_{\imath}$ is the arithmetic mean of $d_{i}$, and $S_{d_{i}}$ is the standard deviation of $d_{i}$.

Moreover, the analysis used demographic and spatial ruralisation indicators. The first of them - the demographic ruralisation rate ${ }^{20}$ - was calculated as a percentage of population living in rural areas (out of the cities) in the total population in a subregion. The spatial ruralisation rate, on the other hand, was calculated as the percentage proportion of rural areas (beyond the administrative borders of cities) in the total area of a subregion.

\section{Research results}

The calculations allowed ranking the subregions from the highest to the lowest value:

\footnotetext{
${ }^{18}$ B. Borkowski, H. Dudek, W. Szczesny: Ekonometria, wybrane zagadnienia. Wydawnictwo Naukowe PWN, Warszawa, 2004.

${ }^{19}$ Z. Hellwig: Zastosowanie metody taksonomicznej do typologicznego podziału krajów ze względu na poziom rozwoju i strukturę kwalifikowanych kadr. Przegląd Statystyczny, 4/1968, 307-328.

${ }^{20}$ Wskaźnik ruralizacji zastosowany został m.in. w następujących pracach badawczych: K. Janc, K. $£$. Czapiewski: Wykształcenie czynnikiem wspierającym rozwój gospodarczy obszarów wiejskich [w:] B. Głębocki, U. Kaczmarek (red.): Obszary sukcesu na polskiej wsi. Studia Obszarów Wiejskich, Tom 8, Instytut Geografii i Przestrzennego Zagospodarowania PAN, Warszawa 2005; D. Śledź (red): Analiza sytuacji na regionalnym rynku pracy. Raport końcowy z realizacji zadań Polskiego Towarzystwa Statystycznego O/Olsztyn, Konsorcjum Olsztyńska Szkoła Biznesu - ASM Sp. z o.o. - Polskie Towarzystwo Statystyczne, Olsztyn 2005.
} 
- $1^{\text {st }}$ class (high level of development): $d_{i}>0.444$,

- $2^{\text {nd }}$ class (medium level of development): $0.261<d_{i} \leq 0.444$,

- $\quad 3^{\text {rd }}$ class (low level of development): $d_{i} \leq 0.148$.

The first place was taken by Olsztyński subregion with the measure of 0.519 , amounting to half of the reference value (the pattern $=1.0$ ). This means that some of the variables in this subregion might assume the most favourable values (or almost the best ones). Olsztyński and Białostocki subregions were included in the $1^{\text {st }}$ class - with a high level of socio-economic development. There were six subregions in the group of the medium level of development. Łomżyński subregion took the last place and it was the only one classified in the $3^{\text {rd }}$ class (the low level of development). Details were presented in Table 3.

Table 3. Classification of subregions according to the level of socio-economic development

\begin{tabular}{|c|c|c|c|}
\hline Place & Subregion & Value of $\boldsymbol{d}_{\boldsymbol{i}}$ & Class \\
\hline 1 & Olsztyński & 0.519 & 1 \\
2 & Białostocki & 0.508 & 1 \\
3 & Elblaski & 0.388 & 2 \\
4 & Krośnieński & 0.308 & 2 \\
5 & Przemyski & 0.244 & 2 \\
6 & Ełcki & 0.238 & 2 \\
7 & Chełmsko-Zamojski & 0.192 & 2 \\
8 & Bialski & 0.158 & 2 \\
9 & Lomżyński & 0.107 & 3 \\
\hline
\end{tabular}

Source: Author's calculation.

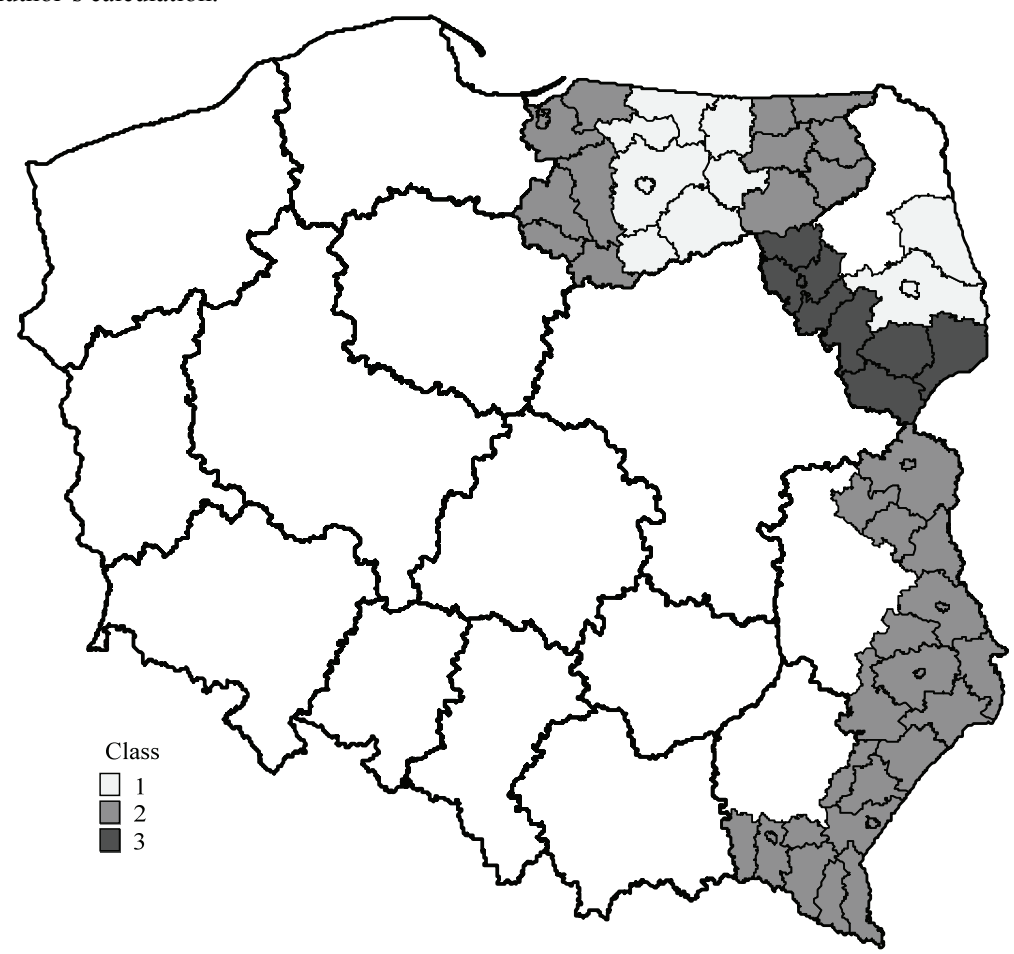

Figure 1. Spatial diversity of subregions in terms of the level of socio-economic development in 2008-2018 Source: Author's elaboration. 
Figure 1 presents spatial distribution of the subregions according to the socioeconomic development classes. Olsztyński and Białostocki subregions, relatively best developed, are located in the northern part of the studied area. However, Łomżyński subregion, the last one in the ranking, is a West-South neighbour of Białostocki subregion.

The results are - to a large extent - consistent with the analysis of Polish subregions in terms of economic development and living standards conducted by T. Czyż ${ }^{21}$ using data from 2008, which means that the average distribution of the subregions in the years 2008-2018 did not deviate significantly from the distribution in the base year.

Table 4 presents the average values of selected demographic indicators that characterize each of the subregions' development classes. The most favourable values (the lowest for destimulants and the highest for stimulants) do not characterize only subregions with the high level of development (Olsztyński and Białostocki). In three cases out of seven, the best values of the indices was characterized by the Łomżyński subregion, indicated in the analysis as the weakest one. Considering positive population growth and quite low values of post-working-age population per 100 working-age population or proportion of population aged 65+ (compared to the average values in both higher development classes), it can be concluded that the demographic situation of Łomżyński subregion is not much unfavourable. Nevertheless, in the analysed period the population was decreasing there (caused by migrations), and as much as $53 \%$ of the population lived in the rural areas.

Table 4. Average values of selected demographic indicators for the development classes

\begin{tabular}{|c|c|c|c|}
\hline \multirow{2}{*}{ Demographic indicator } & \multicolumn{3}{|c|}{ Class } \\
\hline & 1 & 2 & $3 *$ \\
\hline Population density (population per $1 \mathrm{~km} 2$ ) & 79.5 & 69.5 & 46.1 \\
\hline $\begin{array}{l}\text { Change in the number of residents per } 1000 \text { population (combining natural increase } \\
\text { and migrations) }\end{array}$ & 0.9 & -0.9 & -3.6 \\
\hline Natural increase per 1000 population & 0.0 & -0.3 & 0.6 \\
\hline Old-age dependency ratio & 20.2 & 20.5 & 24.5 \\
\hline Post-working-age population per 100 working-age population & 29.0 & 28.4 & 26.0 \\
\hline Proportion of population aged $65+(\%)$ & 15.3 & 15.0 & 13.5 \\
\hline Demographic ruralization index (\%) & 32 & 56 & 53 \\
\hline
\end{tabular}

* values for Łomżyński subregion.

Source: Author's calculation.

The data presented in Table 5 more clearly indicate the dominance of high development subregions. The $1^{\text {st }}$ class was characterized by almost $30 \%$ higher average GDP per capita and the proportion of employees in the services sector, as well as a higher rate of entrepreneurship, a higher proportion of own revenues in the budget (and thus a greater autonomy of the use of the budget funds) as well as a higher proportion of investment expenditure. There were also the lowest values of destimulants, such as the proportion of employed in the agricultural sector, the proportion of long-term unemployed and the proportion of registered unemployed graduates. Nevertheless, it was in Łomżyński subregion where the registered unemployment rate amounted to the lowest

21 T. Czyż: Poziom rozwoju społeczno-gospodarczego Polski w ujęciu subregionalnym, Przegląd Geograficzny, nr 84/2, 2012, 226 i 228. 
average value. Considering this subregion, there was the lowest number of foundations, associations and social organizations registered (per 10,000 inhabitants) - but the gap between Łomżyński subregion and other classes was not significant. In the analysed period, in the same subregion, the proportion of investment expenditure of municipalities and poviats was almost equal to the proportion observed in Olsztyński and Białostocki subregions. In the future it may result in the improvement of other indicators, not only economic, but also infrastructural and demographic ones. This is significant because, as P. Śleszyński writes ${ }^{22}$, the low level of awareness of the inhabitants of peripheral villages and the lack of private financial resources are often important negative factors hindering infrastructural modernization.

Table 5. Average values of selected economic indicators for the development classes

\begin{tabular}{|l|r|r|r|}
\hline \multicolumn{1}{|c|}{ Economic indicator } & \multicolumn{2}{c|}{ Class } \\
\cline { 2 - 4 } & \multicolumn{1}{c|}{$\mathbf{1}$} & \multicolumn{2}{c|}{$\mathbf{3}^{*}$} \\
\hline GDP per capita (PLN) & $\mathbf{3 4 2 0 3 . 9}$ & 24747.1 & 26396.1 \\
\hline Proportion of employed in services (\%) & $\mathbf{6 1}$ & 44 & 37 \\
\hline Proportion of employed in agriculture (\%) & $\mathbf{1 6}$ & 35 & 43 \\
\hline Total registered unemployment rate (\%) & 13.9 & 16.2 & $\mathbf{1 1 . 0}$ \\
\hline $\begin{array}{l}\text { Proportion of long-term unemployed (over 12 months) in population of } \\
\text { unemployed (\%) }\end{array}$ & $\mathbf{3 7 . 4}$ & 40.2 & 38.9 \\
\hline Proportion of unemployed school-leavers in population of unemployed (\%) & $\mathbf{4 . 2}$ & 4.9 & 5.9 \\
\hline Economic entities registered in the REGON per 10000 population & $\mathbf{9 3 0 . 5}$ & 727.9 & 693.8 \\
\hline Foundations, associations and social organizations per 10,000 population & 31.8 & $\mathbf{3 2 . 8}$ & 31.3 \\
\hline $\begin{array}{l}\text { Proportion of own revenues of municipalities and poviats in total budget } \\
\text { revenues (\%) }\end{array}$ & $\mathbf{5 4 . 5}$ & 19.9 & 19.6 \\
\hline $\begin{array}{l}\text { The EU funds for municipalities and poviats for financing programmes and } \\
\text { projects (in PLN per capita) }\end{array}$ & 10.0 & $\mathbf{2 6 . 0}$ & 8.6 \\
\hline $\begin{array}{l}\text { Proportion of investment expenditure of municipalities and poviats in the total } \\
\text { expenditure of municipalities and poviats (\%) }\end{array}$ & $\mathbf{2 0 . 0}$ & 16.6 & 19.5 \\
\hline
\end{tabular}

* values for Łomżyński subregion.

Source: Author's calculation.

Table 6 presents the average values of selected infrastructure indicators. Subregions in the $1^{\text {st }}$ class were characterized by the largest number of beds per 1000 inhabitants, partly the resultant number of tourists accommodated and the highest density of bicycle paths. On the other hand, in the $2^{\text {nd }}$ class subregions there were relatively fewest municipal and poviat roads with a ground surface and the largest number of permanent border crossings. Values of spatial ruralisation were similar in the analysed groups, but the lowest value was observed in the $1^{\text {st }}$ class.

${ }^{22}$ P. Śleszyński: Wydatki związane z infrastrukturą techniczną [w:] Studia nad chaosem przestrzennym, Studia KPZK, tom 182/2018, 199. 
Table 6. Average values of selected infrastructural indicators for the development classes

\begin{tabular}{|c|c|c|c|}
\hline \multirow{2}{*}{ Infrastructural indicator } & \multicolumn{3}{|c|}{ Class } \\
\hline & 1 & 2 & $3 *$ \\
\hline Tourist bed places per 1000 population & 20.2 & 19.5 & 6.9 \\
\hline Tourists accommodated per 1000 population & 732.4 & 496.2 & 291.2 \\
\hline Length of municipal and poviat roads with ground surface in $\mathrm{km}$ per $100 \mathrm{~km}^{2}$ & 43.4 & 38.1 & 61.5 \\
\hline Length of bike paths per $10,000 \mathrm{~km}^{2}(\mathrm{~km})$ & 218.4 & 130.3 & 104.0 \\
\hline Number of permanent border crossings & 3.5 & 3.7 & 3.0 \\
\hline Spatial ruralization index $(\%)$ & 95,7 & 96,8 & 96,2 \\
\hline
\end{tabular}

* values for Łomżyński subregion.

Source: Author's calculation.

As research shows (among others: T. Czyż ${ }^{23}$, J. Sołtys and S. Dorocki ${ }^{24}$, M. Chrzanowska and N. Drejerska ${ }^{25}$ ) - the eastern border subregions have significantly lower development potential compared to other Polish and European subregions. Poland's membership in the European Union, according to research by W. Bąba ${ }^{26}$, resulted in the "transfer" of this country from the group of "poor newly-acceded EU countries (2004-2006)" to the group of "medium-developed countries", thanks to cofinancing of numerous development projects from the EU budget. Hence, the lowest (in comparison to other development groups) average activity of Łomżyński subregion in terms of spending the EU funds in 2008-2018 may be pessimistic. Nevertheless, the national socio-economic policy should focus on this subregion and the other border subregions (especially non-metropolitan ones) in the coming years.

\section{Conclusions}

The observed border subregions are located peripherally in relation to European and national centres of economic activity, while at the EU level they belong to NUTS-3 units with the lowest transport accessibility.

Among the main features of the studied subregions, determining their socioeconomic situation, these should be mentioned: peripheral location, relatively low transport accessibility, resulting from this relatively low investment attractiveness, a low level of entrepreneurship, a dispersed settlement system, low population density, high population unemployment rate as well as low average income of residents.

Nevertheless, the studied area is diversified in terms of development. Two of the nine subregions analysed were classified into the class of a high level of development.

23 T. Czyż: Poziom rozwoju społeczno-gospodarczego Polski w ujęciu subregionalnym, Przegląd Geograficzny, nr 84/2, 2012, 219-236.

24 J. Sołtys, S. Dorocki: Non-metropolitan Industrial NUTS 3 Sub-regions in the European Union Identification and Typology. Prace Komisji Geografii Przemysłu Polskiego Towarzystwa Geograficznego, Volume 30, Issue 2, 2016, 55-71

${ }^{25}$ M. Chrzanowska, N. Drejerska: Statistical Comparative Analysis of Socio-Economic Development Level of Polish Border Regions (NUTS 3), Proceedings of the International Scientific Conference on Quantitative Methods in Economics - Multiple Criteria Decision Making XVIII, Vratna, Slovakia, The Slovak Society for Operations Research, Department of Operations Research and Econometrics, Faculty of Economic Informatics, University of Economics in Bratislava, May 25-27, 2016, 131.

${ }^{26}$ W. Bąba: Changes in Level of Socio-Economic Development of EU Member Countries in the 2004-2013 Period - Taxonomic Analysis, Proceedings of the 3rd International Conference on European Integration 2016 (ICEI 2016), Technical University of Ostrava, Czech Republic, May 19-20, 2016 
These are metropolitan subregions whose centres are the voivodship major cities: Olsztyn and Białystok. The favourable values of most of the analysed indicators result, to a large extent, from the impact of regional centres on a major part of the subregion's area.

In the analysis, Łomżyński subregion, located in the southern part of the studied area, turned out to be the weakest subregion. The subregion's biggest problems were related to the infrastructure, migration and the labour market. In 2008-2018, this subregion was also characterized by the lowest average values of the entrepreneurship index as well as foundations, associations and social organizations registered per 10,000 residents. Nevertheless, this region has got some development potential. Although the population decreased in the subregion during the analysed period, the natural increase rate was positive. Compared to the average values in the higher development classes, Łomżyński subregion was characterised by the most favourable values of such indices as: post-working-age population per 100 working-age population or proportion of population aged $65+$. Besides, significant activity of local governments was manifested in a relatively high average investment expenditure, even though there was the lowest spending of the EU funds per capita. To sum up, it is hard to predict, if positive demographic variables mentioned above and budget activity continue, resulting in improvement in the socio-economic situation (or at least slowing down unfavourable changes). Global trends related to the ageing of the population as well as depopulation of rural areas may threaten socio-economic development not only of the weakest of the analysed subregions, but also of six subregions of the $2^{\text {nd }}$ class.

\section{References}

Balińska A.: Znaczenie turystyki w rozwoju gmin wiejskich na przykładzie obszarów peryferyjnych wschodniego pogranicza Polski. Wydawnictwo SGGW, Warszawa 2016.

Bank Danych Lokalnych GUS [w:] https://bdl.stat.gov.pl/BDL/start (dostęp: 19.06.2019).

Baba W.: Changes in Level of Socio-Economic Development of EU Member Countries in the 2004-2013 Period - Taxonomic Analysis, Proceedings of the 3rd International Conference on European Integration 2016 (ICEI 2016), Technical University of Ostrava, Czech Republic, May 19-20, 2016.

Benedek J., Veress N.C.: Economic disparities and changes in the convergence of the Romanian NUTS 2 and NUTS 3 regions. Romanian Review of Regional Studies, Volume IX, Number 1, 2013, 85-90.

Borkowski B., Dudek H., Szczesny W.: Ekonometria, wybrane zagadnienia. Wydawnictwo Naukowe PWN, Warszawa, 2004.

Chrzanowska M., Drejerska N.: Statistical Comparative Analysis of Socio-Economic Development Level of Polish Border Regions (NUTS 3), Proceedings of the International Scientific Conference on Quantitative Methods in Economics - Multiple Criteria Decision Making XVIII, Vratna, Slovakia, The Slovak Society for Operations Research, Department of Operations Research and Econometrics, Faculty of Economic Informatics, University of Economics in Bratislava, May 25-27, 2016.

Czarnecki A.: Wpływ czynników lokalizacyjnych na rozwój działalności pozarolniczej na obszarach wiejskich. Roczniki Naukowe SERiA, tom VIII, zeszyt 4, 2006, 78-82.

Czyż T.: Poziom rozwoju społeczno-gospodarczego Polski w ujęciu subregionalnym, Przegląd Geograficzny, nr 84/2, 2012, 219-236. 
Drejerska N. Chrzanowska M. Pomianek I. Strefa podmiejska Warszawy: wybrane zagadnienia (Warsaw Suburban Area: Selected Issues). Wydawnictwo SGGW, Warszawa 2014.

Heffner K.: Wielofunkcyjność obszarów wiejskich w Polsce rzeczywistość czy mit? [w:] W. Kamńska, K. Heffner (red.): Obszary wiejskie, wielofunkcyjność, migracje, nowe wizje rozwoju, Studia KPZK, 2011, nr 133, 10.

Hellwig Z.: Zastosowanie metody taksonomicznej do typologicznego podziału krajów ze względu na poziom rozwoju i strukturę kwalifikowanych kadr. Przegląd Statystyczny, 4/1968, 307-328.

Hryniewicz J.T.: Teoria „centrum-peryferie” w epoce globalizacji. Studia Regionalne i Lokalne, Nr 2(40) 2010, 5-27.

https://granica.gov.pl/przejsciap.php (dostęp: 20.06.2019)

Grosse T. G.: Wybrane koncepcje teoretyczne i doświadczenia praktyczne dotyczące rozwoju regionów peryferyjnych. Studia Regionalne i Lokalne, Nr 1(27)2007, 27-49.

Jakubowski A., Bronisz U.: Granica Unii Europejskiej jako czynnik (dez)aktywizujący rozwój i konkurencyjność obszarów przygranicznych [w:] Grynia A. (red.): Wybrane aspekty rozwoju i konkurencyjności nowych krajów członkowskich Unii Europejskiej, Wydział EkonomicznoInformatyczny w Wilnie, Uniwersytet w Białymstoku, Wilno 2015, 627-639.

Janc K., Czapiewski K. Ł.: Wykształcenie czynnikiem wspierającym rozwój gospodarczy obszarów wiejskich [w:] Głębocki B., Kaczmarek U. (red.): Obszary sukcesu na polskiej wsi. Studia Obszarów Wiejskich, Tom 8, Instytut Geografii i Przestrzennego Zagospodarowania PAN, Warszawa 2005.

Kowalska M. (red.), Knapik W., Bogusz M., Kiełbasa B., Niedziółka A., Piotrowska A., Satoła Ł.: Rozwój lokalny obszarów wiejskich w perspektywie społeczno-ekonomicznej, Uniwersytet Rolniczy im. Hugona Kołłąaja ; Europejskie Centrum Badawcze Drobnych Gospodarstw Rolnych, Kraków 2015.

Lengyel I., Kotosz B.: The Catching up Processes of the Regions of the Visegrad Group Countries. Comparative Economic Research, 2018, 21, nr 4, 5-24.

Leszczewska K.: Aktywność ekonomiczna regionów peryferyjnych. Nierówności Społeczne a Wzrost Gospodarczy, zeszyt 17, 2010, s. 215-225.

Łapińska A.: Rola przedsiębiorczości w kreowaniu wielofunkcyjności rozwoju terenów wiejskich. Wieś Jutra, październik 10(123)2008, 8.

Mapa przejść i obiektów Straży Granicznej [w:] https://www.strazgraniczna.pl/pl/mapa-przejsc-iobiektow/ (dostęp: 20.06.2019)

$\mathrm{Na}$ Wschód nie na własnych nogach. Rząd zamyka piesze przejścia graniczne [w:] https://prawo.gazetaprawna.pl/artykuly/1393994,rzad-zamyka-piesze-przejscia-graniczne.html (dostęp: 20.06.2019).

Panzera D., Postiglione P.: Economic growth in Italian NUTS 3 provinces. The Annals of Regional Science 53(1), 2014, 273-293.

Parlińska A., Yavuz H.B.: Finances of municipalities governments in Poland and Turkey. Acta Sci. Pol. Oeconomia 16(4)2017, 123-132.

Parysek J.J.: Rozwój społeczno-gospodarczy oraz czynniki i uwarunkowania rozwoju. [w:] Teoretyczne i aplikacyjne wyzwania współczesnej geografii społeczno-ekonomicznej, Studia KPZK, tom 183/2018, 37-54.

Podstawka M., Suchodolski B.: Rozwój lokalny i jego wyznaczniki na poziomie powiatu. Marketing i Rynek, r. 23, nr 10/2016, CD, 383-393.

Pomianek I.: Poziom rozwoju społeczno-gospodarczego obszarów wiejskich województwa warmińsko-mazurskiego. Acta Sci. Pol. Oeconomia, 9(3)/2010, 227-239.

Proniewski M.: Rozwój regionów peryferyjnych w Unii Europejskiej, Wydawnictwo Uniwersytetu w Białymstoku, Białystok 2012.

Rakowska J.: Zróżnicowanie poziomu rozwoju gmin Polski Wschodniej, Roczniki Naukowe Stowarzyszenia Ekonomistów Rolnictwa i Agrobiznesu, 2011, tom 13, zeszyt 2, 392-397. 
Rakowska J.: Zróżnicowanie poziomu starości demograficznej Polski w ujęciu lokalnym, Studia Ekonomiczne i Regionalne, tom 9, 2/2016, s. 13-23.

Roszko-Wójtowicz E., Grzelak M.M.: Wielowymiarowe ujęcie zróżnicowania poziomu jakości życia w województwach w Polsce. Zeszyty Naukowe Polityki Europejskie, Finanse i Marketing, 69/2018, 197-214.

Rudnicki R.: Peryferyjność położenia geograficzno-komunikacyjnego a wybrane wskaźniki rozwoju powiatów ziemskich, [w:] M. Wesołowska (red.): Wiejskie obszary peryferyjne uwarunkowania i czynniki aktywizacji. Studia Obszarów Wiejskich, tom 26, Warszawa 2011, 160169.

Satoła Ł.: Zróżnicowanie wykorzystania funduszy Unii Europejskiej w układzie centrum peryferia, w: Prace Naukowe Uniwersytetu Ekonomicznego We Wrocławiu, nr 320, 2013, 176185.

Satoła Ł., Pogan P.: Trwały rozwój lokalny w gminach o zróżnicowanej sytuacji finansowej, Zeszyty Naukowe Szkoły Głównej Gospodarstwa Wiejskiego w Warszawie, Ekonomika i Organizacja Gospodarki Żywnościowej, nr 116, 2016, 119-131.

Sołtys J., Dorocki S.: Non-metropolitan Industrial NUTS 3 Sub-regions in the European Union Identification and Typology. Prace Komisji Geografii Przemysłu Polskiego Towarzystwa Geograficznego, Volume 30, Issue 2, 2016, 55-71.

Stanny M.: Przestrzenne zróżnicowanie rozwoju obszarów wiejskich w Polsce (Spatial Diversification of Rural Development in Poland). Problemy Rozwoju Wsi i Rolnictwa, IRWiR PAN, Warszawa 2013.

Śledź D. (red.): Analiza sytuacji na regionalnym rynku pracy. Raport końcowy z realizacji zadań Polskiego Towarzystwa Statystycznego O/Olsztyn, Konsorcjum Olsztyńska Szkoła Biznesu ASM Sp. z o.o. - Polskie Towarzystwo Statystyczne, Olsztyn 2005.

Śleszyński P.: Wydatki związane $\mathrm{z}$ infrastrukturą techniczną [w:] Studia nad chaosem przestrzennym, Studia KPZK, tom 182/2018, 196-228.

Śleszyński P.: Demograficzne wyzwania rozwoju regionalnego Polski [w:] Teoretyczne i aplikacyjne wyzwania współczesnej geografii społeczno-ekonomicznej, Studia KPZK, tom $183 / 2018,225-247$.

\section{Klasyfikacja podregionów przygranicznych Polski Wschodniej według poziomu rozwoju społeczno-gospodarczego}

\section{Streszczenie}

W artykule przeprowadzono klasyfikację podregionów (NUTS 3), na obszarze których znajdowały się stałe przejścia graniczne, pod względem poziomu rozwoju społeczno-gospodarczego. Badaniem objęto 9 podregionów usytuowanych w województwach: warmińsko-mazurskim, podlaskim, lubelskim oraz podkarpackim. Zastosowanie taksonomicznej miary rozwoju Hellwiga umożliwiło pogrupowanie podregionów wg trzech kategorii poziomu rozwoju: wysokiego, średniego oraz niskiego. Relatywnie wysoki poziom rozwoju charakteryzował dwa podregiony metropolitarne: białostocki i olsztyński. Najsłabszym okazał się podregion przemyski, jednak nie był on obszarem pozbawionym zupełnie potencjału rozwojowego. W porównaniu z przeciętnymi wartościami w wyznaczonych wyższych klasach rozwoju, podregion przemyski charakteryzowały: najniższy udział dróg gminnych i powiatowych o nawierzchni gruntowej i największa liczba stałych przejść granicznych. Mimo, że w badanym okresie w podregionie ubywało ludności, przyrost naturalny był dodatni. Ponadto, na terenie podregionu przemyskiego zarejestrowanych było najwięcej (w przeliczeniu na 10 tys. mieszkańców) fundacji, stowarzyszeń i organizacji społecznych, co świadczy o aktywności społecznej. Natomiast znacząca aktywność samorządów lokalnych przejawiała się $\mathrm{w}$ relatywnie wysokim przeciętnym wydatkowaniu środków $\mathrm{z}$ funduszy 
unijnych, co w przyszłości może skutkować poprawą sytuacji społeczno-gospodarczej, m.in. w zakresie infrastruktury, rynku pracy i demografii.

Słowa kluczowe: peryferyjność przestrzenna, peryferyjność gospodarcza, NUTS 3, miara rozwoju Hellwiga

JEL Code: R11

Information about author:

dr inż. Iwona Pomianek

Warsaw University of Life Sciences - SGGW

Institute of Economics and Finance

Department of Development Policy and Marketing

ul. Nowoursynowska 166

02-787 Warsaw, Poland

e-mail: iwona_pomianek@sggw.pl

ORCID: 0000-0002-2858-2714 